\title{
A modeling comparison of deep greenhouse gas emissions reduction scenarios by 2030 in California
}

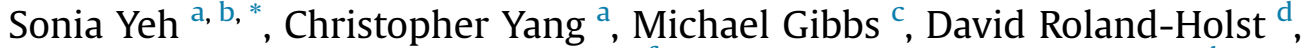 \\ Jeffery Greenblatt ${ }^{\mathrm{e}}$, Amber Mahone ${ }^{\mathrm{f}}$, Dan Wei ${ }^{\mathrm{g}}$, Gregory Brinkman ${ }^{\mathrm{h}}$, \\ Joshua Cunningham ${ }^{\mathrm{c}}$, Anthony Eggert ${ }^{\mathrm{i}}$, Ben Haley ${ }^{\mathrm{f}}$, Elaine Hart ${ }^{\mathrm{f}}$, Jim Williams ${ }^{\mathrm{f}}$ \\ a Institute of Transportation Studies, University of California, 1605 Tilia, Suite \#100, Davis, CA 95616, USA \\ b Department of Energy and Environment, Chalmers University of Technology, SE-412 96 Gothenburg, Sweden \\ c California Air Resources Board, Sacramento, CA 95814, USA \\ d Department of Agricultural and Resource Economics, 207 Giannini Hall, University of California, Berkeley, CA 94720, USA \\ e Energy Analysis and Environmental Impacts Division and Joint Center for Artificial Photosynthesis, Lawrence Berkeley National Laboratory, 1 Cyclotron \\ Road, MS 90-2002, Berkeley, CA 94720, USA \\ ${ }^{\mathrm{f}}$ Energy and Environmental Economics (E3), 101 Montgomery Street, Suite 1600, San Francisco, CA 94104, USA \\ ${ }^{g}$ Sol Price School of Public Policy, University of Southern California, Los Angeles, CA 90089, USA

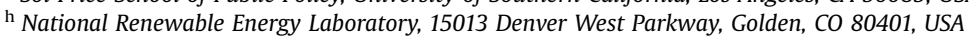 \\ i ClimateWorks Foundation, 235 Montgomery Street, Suite 1300, San Francisco, CA 94104, USA
}

\section{A R T I C L E I N F O}

\section{Article history:}

Received 5 January 2016

Received in revised form 31 August 2016

Accepted 10 October 2016

Available online 21 October 2016

\section{Keywords:}

Modeling comparison

GHG abatement

Non-energy GHG

Emissions reduction scenarios

Climate policies

\begin{abstract}
A B S T R A C T
California aims to reduce greenhouse gas (GHG) emissions to $40 \%$ below 1990 levels by 2030 . We compare six energy models that have played various roles in informing the state policymakers in setting climate policy goals and targets. These models adopt a range of modeling structures, including stockturnover back-casting models, a least-cost optimization model, macroeconomic/macro-econometric models, and an electricity dispatch model. Results from these models provide useful insights in terms of the transformations in the energy system required, including efficiency improvements in cars, trucks, and buildings, electrification of end-uses, low- or zero-carbon electricity and fuels, aggressive adoptions of zero-emission vehicles (ZEVs), demand reduction, and large reductions of non-energy GHG emissions. Some of these studies also suggest that the direct economic costs can be fairly modest or even generate net savings, while the indirect macroeconomic benefits are large, as shifts in employment and capital investments could have higher economic returns than conventional energy expenditures. These models, however, often assume perfect markets, perfect competition, and zero transaction costs. They also do not provide specific policy guidance on how these transformative changes can be achieved. Greater emphasis on modeling uncertainty, consumer behaviors, heterogeneity of impacts, and spatial modeling would further enhance policymakers' ability to design more effective and targeted policies. This paper presents an example of how policymakers, energy system modelers and stakeholders interact and work together to develop and evaluate long-term state climate policy targets. Even though this paper focuses on California, the process of dialogue and interactions, modeling results, and lessons learned can be generally adopted across different regions and scales.
\end{abstract}

๑) 2016 The Authors. Published by Elsevier Ltd. This is an open access article under the CC BY-NC-ND license (http://creativecommons.org/licenses/by-nc-nd/4.0/).

\section{Introduction}

The passage of the California Global Warming Solutions Act of 2006 (AB32) and the adoptions of wide-ranging implementation

\footnotetext{
* Corresponding author. Chalmers University of Technology, Energy and Environment, SE-412 96 Gothenburg, Sweden.

E-mail address: sonia.yeh@chalmers.se (S. Yeh).
}

plans [1,2] make California a leader in developing and implementing policies that reduce greenhouse gas (GHG) emissions, improve air quality, and promote efficient use of energy and other resources [3-6]. The current climate law, $A B 32$, required the state to reach 1990 levels by 2020. In August 2016, California passed SB32 requiring the California Air Resources Board (ARB) to ensure that statewide GHG emissions are reduced to $40 \%$ below 1990 levels by 2030 [7]. 
Policymakers should rely on transparent and high-quality technical and economic models to help evaluate plausible future emission scenarios and assess environmental and economic impacts of current or proposed emission targets and policy instruments. There is a rich modeling comparison literature focused on understanding the range of mitigation options for abating climate change [8-13] by comparing input assumptions and the results across a range of relevant models and exploring the underlying causes contributing to the observed differences [14]. These differences can result from: (1) assumptions about activity drivers and technologies and mitigation costs and options available between now and 2050; (2) structure and level of detail of the models (e.g. macroeconomic vs. sectoral-specific vs. technology-detailed model); (3) the model solution method (equilibrium vs. optimization vs. scenarios-based); and (4) scope and system boundaries of the models (multi-state vs. California-only, single-sector vs. economy-wide), etc.

This paper is a summary of the California Climate Policy Modeling (CСPM) workshop, held on February 23, 2015 (https:// policyinstitute.ucdavis.edu/initiatives/ccpm/). It brought together energy economic modelers, academics, policymakers (including the senior advisor in the governor's office and the Executive Officer of ARB), lawmakers and stakeholders (including industry representatives, environmental non-governmental organizations NGOs, and environmental justice communities) reviewing the current status of energy models and examining pathways to meet longterm climate abatement objectives in California. Our paper focuses on the following metrics highlighted by both modelers and policymakers in the first CCPM workshop [13]: (1) common insights and divergence across models; (2) the implied technical/ socioeconomic hurdles of given scenarios and economic costs; (3) performance metrics (e.g. $\mathrm{gCO}_{2} \mathrm{e} /$ mile for vehicles, carbon intensity of fuels and electricity, share of renewable electricity generation) and economic metrics (e.g. \$/metric ton $\mathrm{CO}_{2} \mathrm{e}$, percent change of household expenditure on energy, costs of travel); and (4) the limitations of the modeling approaches and the issue of uncertainty. These models can inform policy by elucidating scenarios of specific sets of technology and resource options for GHG mitigation and their timing. The workshop also highlighted the caveats of the models and levels of uncertainties. We steer away from the discussion of policy needs and needs for specific policy instruments, as this will be the focus of future workshops.

In Section 2, we introduce the different modeling types included in this modeling comparison workshop, the pros and cons of each model, and the key findings from each study. We compare the key results of deep GHG mitigation scenarios in 2030 by sector in Section 3. In Section 4, we summarize the key findings consistent across models, and the opportunities as well as challenges in using models to inform policymakers when setting long-term policy goals and targets.

\section{Methods}

We briefly describe the models examined in this paper, focusing on the structure of the model (as opposed to different assumptions used in the models) and the key insights from each model. We limit our review of the results to 2030 as it is the target year for the next major policy discussion [2,15]. Almost all of the models reviewed here analyze emissions to 2050 and many achieve the $80 \%$ GHG reduction target for 2050. All the models reviewed here have conducted extensive sensitivity analysis or uncertainty analysis to explore a wide range of scenarios that are published elsewhere. For simplicity, our review here only focuses on the "main" scenarios. Not all scenarios reviewed in this paper achieve $40 \%$ reduction below 1990 level by 2030. As we have shown previously, models that meet the 2050 target do not necessarily meet the newly proposed 2030 target: 40\% reduction below 1990 level by 2030. We will show later in the article that setting the 2030 target clearly influences the trajectory of how the 2050 target is achieved.

The structure and methods of a model determine the types of questions that the models are suitable to answer. The modeling types included in this review range from scenario-based stockturnover model (PATHWAYS [16] and CALGAPS [17]), bottom-up optimization (CA-TIMES [18]), computable general equilibrium model (BEAR [19]), macro-econometric (REMI PI+ [20,21]) model, and economic-dispatch model for the electricity sector (LCGS [22]) (Table 1).

In a scenario-based stock-turnover model (which can be forecastbased or backcast-based), the rate and type of technology adoptions and resources use are determined based on modelers' judgments. These models calculate the portfolio of technology stock (and sometimes, but not always, costs) over time based on the lifetime of technology and their retirement rates. They are suited to answer "what if" questions (i.e. what is the impact if these technologies are adopted), as it has a high degree of transparency and traceability with regards to the assumptions and the impacts of the assumptions on the results. A limitation of these models is that they may rely too much on experts' assumptions with regards to technology penetration rates.

A bottom-up optimization model optimizes technology investment decisions based on the overall costs of the system. The model minimizes total system costs when demands for energy services are fixed or maximizes social welfare if demands for energy services are responsive to price changes. The model assumes perfect foresight and makes investment decisions solely based on the costs of technology, and resources from the perspective of a single decision-maker. It is therefore suited to ask the question: "What are the socially optimal (i.e. least-cost) technology and resource options to achieve a policy target, especially those that exhibit tradeoffs across sectors. One of the downsides of this type of model is that real-world decisions often involve markets, which are not represented in these models and consumer choices are rarely made solely on costs alone; significant heterogeneity exists in consumer demand and consumer preferences [23]. Factors such as convenience, familiarity with technologies, risk attitude, or market barriers (e.g. lack of awareness) often dominate consumers' decisions [24], which are not usually included in the optimization framework.

A macro-econometric model is usually constructed using statistical estimation methods based on pooled time series and regional (panel) data. Its forecasting strengths are to relate the role of government, capital markets, and other trading partners to account for economy-wide resource allocation, production, and income determination. While the other models focus primarily on the quantities of low-carbon technologies and resources and their direct costs, macroeconomic models such as macro-econometric model or computable general equilibrium (CGE) models accounts for economy-wide impacts (both direct and indirect) of these technology/resource shifts on consumption, employment, and income, brought about by the adoption of alternative technologies and resources. A typical drawback of these types of models is that most of these models make relatively simple assumptions about technology types, costs and operation decisions. Thus they are suitable for asking high-level, macro economy questions pertaining to income growth, labor markets, GDP impacts, economy feedback at the sectoral level, etc. even though they are typically vague about the impacts of specific technology pathways or choices.

An economic-dispatch production simulation model for the electric sector optimizes operating decisions at very high temporal resolutions to supply electricity demand at the lowest cost, 
Table 1

Characteristic of models included in the modeling comparison.

\begin{tabular}{|c|c|c|c|c|c|}
\hline Model & $\begin{array}{l}\text { Version used in this } \\
\text { comparison }\end{array}$ & Scope & Modeling type & $\begin{array}{l}\text { Type(s) of policy } \\
\text { questions the model is } \\
\text { suited for }\end{array}$ & $\begin{array}{l}\text { GHG Scenario: \% cut } \\
\text { below } 1990 \text { in } 2030\end{array}$ \\
\hline \multicolumn{6}{|c|}{ System-wide, economy-wide model } \\
\hline E3 PATHWAYS v.2.3.1 & Mahone, Hart [16] & Economy-wide & $\begin{array}{l}\text { Scenario-based } \\
\text { infrastructure and stock } \\
\text { model }\end{array}$ & $\begin{array}{l}\text { What-if technology- } \\
\text { based backcasting } \\
\text { exercise }\end{array}$ & $\begin{array}{l}33 \% \text { (Straight Line } \\
\text { scenario) }\end{array}$ \\
\hline $\begin{array}{l}\text { CA GHG Analysis of } \\
\text { Policies Spreadsheet } \\
\text { (CALGAPS) }\end{array}$ & Greenblatt [17] & Economy-wide & $\begin{array}{l}\text { Scenario-based stock } \\
\text { model }\end{array}$ & $\begin{array}{l}\text { What-if technology and } \\
\text { policy-implementation } \\
\text { analysis }\end{array}$ & $27 \%(S 2), 47 \%(S 3)$ \\
\hline CA-TIMES & Yang, Yeh [18] & Economy-wide & $\begin{array}{l}\text { Least-cost optimization. } \\
\text { Also tracks technology } \\
\text { and infrastructure } \\
\text { turnover. }\end{array}$ & $\begin{array}{l}\text { Least-cost technology } \\
\text { pathways to achieve a } \\
\text { policy target }\end{array}$ & $33 \%$ \\
\hline $\begin{array}{l}\text { Berkeley Energy and } \\
\text { Resources (BEAR) }\end{array}$ & Roland-Holst [29] & Economy-wide & $\begin{array}{l}\text { Recursive dynamic } \\
\text { computable general } \\
\text { equilibrium (CGE) }\end{array}$ & $\begin{array}{l}\text { Economy-wide impacts } \\
\text { of climate mitigations } \\
\text { (e.g. GDP, jobs, } \\
\text { employment, income, } \\
\text { government spending) }\end{array}$ & $\begin{array}{l}\text { 27\% (incremental), } 42 \% \\
\text { (progressive) }\end{array}$ \\
\hline \multicolumn{6}{|l|}{ Sectoral/regional models } \\
\hline $\begin{array}{l}\text { REMI Policy Insight Plus } \\
\text { (REMI PI+) }\end{array}$ & $\begin{array}{l}\text { Rose, Wei [21], Wei and } \\
\text { Rose [22] }\end{array}$ & $\begin{array}{l}\text { Economy-wide, Southern } \\
\text { California only }\end{array}$ & Macroeconometric model & $\begin{array}{l}\text { Economy-wide impacts } \\
\text { of climate mitigations } \\
\text { (e.g. GDP, jobs, } \\
\text { employment, income, } \\
\text { government spending) }\end{array}$ & \\
\hline $\begin{array}{l}\text { Low Carbon Grid Study } \\
\text { (LCGS) }\end{array}$ & LCGS [48] & $\begin{array}{l}\text { Electric sector only, } \\
\text { western grid }\end{array}$ & $\begin{array}{l}\text { Economic dispatch } \\
\text { production cost model }\end{array}$ & $\begin{array}{l}\text { More realistic system } \\
\text { response of the electric } \\
\text { sector to potential } \\
\text { system, price, technology, } \\
\text { or policy changes }\end{array}$ & \\
\hline
\end{tabular}

given the operational and reliability limitations within an area's generation fleet and transmission system. This type of model is designed to understand impacts of changes in the electric sector, particularly in terms of operating, dispatching, storage and investment decisions. The downside of these models is that demands for electricity (including total demand level as well as the hourly and seasonal patterns of demands) need to be exogenously projected to the future. Because they lack system perspective outside of the electricity sector, they cannot anticipate nor endogenously estimate possible shifts in demand level (such as increased electricity demand due to increased adoption of electric vehicles, $\mathrm{EV}$, or demand reduction in response to higher prices), time of use (due to demand response policies or EV charging behavior), or interactions with the other sectors. Though these interactions can be handled via scenario analyses, they can only be estimated exogenously or iterated externally with other economywide models.

In the sections below, we briefly highlight key modeling results of deep GHG mitigation scenarios examined in these models.

\subsection{E3 California PATHWAYS model}

E3's PATHWAYS model is a "bottom-up" scenario model that includes detailed technology representation of the buildings, industry, transportation and electricity sectors (including hourly electricity supply and demand) and explicitly models stocks and replacement of buildings, vehicles and appliances [16]. Demand for energy is driven by forecasts of population, building square footage, and other energy services. The E3 team developed GHG mitigation scenarios that achieved statewide GHG emission reductions of 26-38\% below 1990 levels by 2030 (319-268 million metric tons (MMT) $\mathrm{CO}_{2} \mathrm{e}$ ), all of which are potentially consistent with an $80 \%$ reduction by 2050 as shown in the previous CCPM exercise [13]. These reductions come about due to what $\mathrm{E} 3$ termed the " 5 pillars" of mitigation options:
- Efficiency and conservation in buildings, vehicles and industry. Energy use per capita is reduced from $140 \mathrm{MMBtu} /$ person in 2015 to $95 \mathrm{MMBtu} /$ person in 2030 and $60 \mathrm{MMBtu} /$ person in 2050 , or $40 \%$ below the projected 2050 reference case of 100 MMBtu/person.

- Fuel switching away from fossil fuels to low-carbon electricity and hydrogen $\left(\mathrm{H}_{2}\right)$ fuel including electrification of end-use technologies in the building and transportation sectors. By 2030, the share of low-carbon electricity reaches $23 \%$ of total final energy in 2030 and over $40 \%$ in 2050 from today's $18 \%$.

- Decarbonize electricity through the expansion of renewables ( $50-60 \%$ renewables in 2030 in CA). In 2030, the emissions intensity of electricity is reduced by $35 \%$ to $0.17 \mathrm{tCO}_{2} \mathrm{e} / \mathrm{MWh}$. Continued decarbonization reduces emission intensity by $80 \%$ to $0.05 \mathrm{tCO}_{2} \mathrm{e} / \mathrm{MWh}$ in 2050.

- Decarbonize fuels (liquid and gas) through greater use of biomass with significant quantities of sustainable biofuels displacing liquid or gaseous fossil fuels. Biofuels (renewable diesel and biogas) constitute 22\% total transportation final energy demand, or 450-620 PJ, in 2030.

- Reductions in non-energy GHGs (primarily methane and fluorinated ( $\mathrm{F}$ ) gases). Non-energy, non- $\mathrm{CO}_{2} \mathrm{GHG}$ emissions are currently at $62 \mathrm{MMTCO}_{2} \mathrm{e} / \mathrm{yr}$ and expected to rise to 80 $\mathrm{MMTCO}_{2} \mathrm{e} / \mathrm{yr}$ by 2050 . The study suggests mitigation potential is high for F-gases, methane leaks and some types of waste and manure, but it may be difficult to mitigate cement, enteric fermentation, and other agricultural non-energy GHG emissions. The study examined approaches for reducing emissions from these sources to 35\% below 1990 levels by 2050, requiring greater reductions from energy-related sources.

One of the key points discussed in the PATHWAYS project is the issue of potential "forks in the road", in which technology decisions lead to the adoption of specific options in one sector versus another (i.e. "path-dependency" of technology development [25,26]). One 
example given was the potential for using $\mathrm{H}_{2}$ production via electrolysis (9 GW in 2030 operating at $25 \%$ load factor) as a flexible electricity load for fuel production and grid balancing. ${ }^{1}$ If flexible fuel production is not available, significant quantities of longduration (diurnal) electricity storage may be needed by 2030 if electricity markets are not made more efficient than today. Another example is the tradeoff between utilizing limited supplies of biomass for making liquid biofuels and producing biogas for buildings. If biomass is used to produce liquid biofuels for transportation, then biomass cannot be used to decarbonize the gas pipeline and electrification of buildings would need to be a main strategy to reduce emissions from buildings. Alternatively, biogas could replace $50 \%$ of fossil natural gas in buildings and industry, but would result in lower biofuels production and require greater electrification in the transport sector.

\subsection{CA GHG Analysis of Policies Spreadsheet (CALGAPS) model}

The California GHG Analysis of Policies Spreadsheet (CALGAPS; formerly GHGIS) model [17] tracks all GHG-emitting sectors within California between 2010 and 2050: light-duty vehicles, heavy-duty vehicles, other transportation (rail, airplanes, marine), stationary end uses (residential, commercial, industrial, municipal, agriculture), water, hydrogen, electricity, fuels (fossil- and biomass-based), high global warming potential gases, and other non-energy emissions (petroleum extraction, cement, landfills, waste, agriculture and forestry). Unlike the other models, CALGAPS also estimates emissions of three criteria pollutants ( $\mathrm{ROG}, \mathrm{NO}_{\mathrm{x}}$, and $\mathrm{PM}_{2.5}$ ), though the analysis focus is GHG emissions. Input data for the model was assembled from a combination of public and proprietary data supplied by a number of state agencies.

The CALGAPS model primarily focuses on understanding the implications of meeting existing (i.e. Committed)(S1) and potential future (i.e. uncommitted) (S2 and S3, see below) state policies against a counterfactual with no policies (SO). The model and analysis provide a useful benchmark for understanding the potential suite of state policies to reduce GHG emissions relative to a baseline scenario (SO), all based on technologies or measures that are available today. Therefore it is important to note that the scenarios are not specifically designed to hit the 2030 or 2050 target, but to explore the impacts of GHG policy scenarios in terms of energy use and GHG emissions.

A series of scenarios were developed based on 49 specific state and federal policies, including some that are Uncommitted (S2) and Potential Policy and Technology Futures (S3). The model estimates the GHG reduction impacts of each policy individually and in various combinations in a sensitivity analysis, but does not explicitly consider technology or policy costs. Monte Carlo simulation is used to provide uncertainty bounds on projected GHG emissions pathways, and is found to be driven primarily by uncertainty in population, state GDP and building efficiency improvements. Given that the existing and uncommitted policies are generally nearer term policies, they lead to substantial reductions in the 2030 timeframe, but do not achieve the very deep 80\% reduction by 2050 . Additional policy levers or more stringent versions of existing or proposed policies would be needed. Another key insight of this analysis is that even with GHG trajectories that do not meet the 2050 target, the early reductions in emissions associated with S3 could lead to lower cumulative emissions when compared to a straight-line reduction between 2020 and 2050

\footnotetext{
${ }^{1}$ Electrolysis can be operated in a relatively constant manner or in a way that responds to grid conditions, which may be useful for grid balancing for electricity grids with high intermittent renewable penetration.
}

targets $[13,17]$. The model suggests that the top five policies that reduce the most state-wide GHG emissions by 2030 (>20 $\mathrm{MMTCO}_{2} \mathrm{e} / \mathrm{yr}$ ) are [17]:
- AB 1493 (Pavley) light-duty vehicle (LDV) efficiency/GHG standards,
- Renewable Portfolio Standard (RPS) 33\% target,
- SB 1368 imported coal power phase-out,
- California Public Utilities Commission (CPUC) Strategic Plan (uncommitted, S2) for efficient buildings, and
- Hydrofluorocarbon (HFC) gas phase-out.

Among potential policies (S3), vehicle miles traveled (VMT) reduction and increasing the RPS to $50 \%$ can reduce the most emission reductions by 2030 .

\subsection{California TIMES (CA-TIMES) model}

CA-TIMES is a technology-rich, bottom-up, optimization model of the California Energy System. The model covers all sectors of the economy, excluding emissions from non-energy sources, and the main demand drivers for the model are projections of energy service/fuel demands across the various end-use sectors (residential, commercial, transportation, industrial and agricultural sectors). The CA-TIMES model makes optimized technology investment and operation decisions (from a social planner's perspective) across the entire energy system to satisfy the projected end-use service demands over the modeling timeframe out to 2050 [18,27]. These investment decisions include primary energy resource extraction, fuel production/conversion from a variety of resources, fuel imports/exports, electricity production, and end-use appliances in the buildings and transportation end-use sectors. The representation of the industrial and agricultural sectors is simply modeled as exogenous demands for fuels and electricity use without any technology details. The CA-TIMES model is unique among the models presented in this paper in that it optimizes emission reductions across the entire energy system to determine the least-cost mitigation pathways. The model minimizes overall system cost (the net present value of all annualized investment/capital costs, fuel costs, and operating and maintenance (O\&M) costs and in some sectors, utilizes high technology-specific discount rates (10-50\%) to represent consumers' preference for short payback for investments in energy efficient appliances). This integration of decisions across the entire energy system manifests itself in some results where the model trades off different mitigation options across various sectors to achieve the lowest system cost.

The modeling results, based upon a straight-line trajectory between 2020 and 2050 ("GHG-Line"), show that deep reductions in GHGs require major energy transformations (from energy efficiency, electrification, high renewable generation in the electric sector, low-carbon transportation fuels, and advanced vehicle technologies) and that achieving these goals is possible at reasonable average carbon reduction cost ( $\$ 9$ to $\$ 124 /$ tonne $\mathrm{CO}_{2} \mathrm{e}$ at $4 \%$ discount rate) relative to a baseline scenario (or business-as-usual, BAU, scenario). In the 2030 timeframe, changes that are seen in the primary scenario include a $31 \%$ reduction in petroleum use in onroad transportation, 2.4 million light-duty zero and partial ZEVs on the road, between 38 and $49 \%$ electricity generation from renewables, significant increases in building efficiency $(\sim 2 \times)$ by 2030 , at relatively low cost for achieving these targets (relative to the BAU scenario) as costs range between $\$ 26$ to $\$ 38 /$ capita/yr to 2030 when comparing to one of the BAU scenarios. A range of alternative scenarios was explored to understand the role and sensitivity of emissions reductions to various technologies such as nuclear power, carbon capture and sequestration (CCS), additional renewable 
and biomass resources, and demand elasticity. The results of the sensitivity analysis were published elsewhere [18].

\subsection{Berkeley Energy and Resources model}

The Berkeley Energy and Resources (BEAR) model is a detailed dynamic computable general equilibrium (CGE) model that traces the complex linkage effects across the California economy as these arise from changing policies and external conditions [28]. The BEAR model utilizes a nested CES (Constant Elasticity of Substitution) for energy sources and production more broadly, and has four components: a) core general equilibrium model, b) technology module, c) electricity module, and d) transportation module. The main focus of this model is to analyze the broader economic impacts of specific emissions mitigation activities (such as the electricity generation or transportation technology mix) that are exogenously specified. This enables the model to assess the effects of broad changes in resource usage, and energy consumption and expenditures on state Gross Domestic Product (GDP) and employment. Model outputs of these impacts include detailed patterns of resource/energy use, supply, demand, trade, employment, emissions, public expenditure and revenue, prices, and incomes. The trade and labor movement between the state, the rest of the U.S., and abroad are also modeled endogenously [28].

The modeling results indicate that if California achieves the fairly aggressive $2030 \mathrm{GHG}$ target (40\% below 1990 levels) the state economy can benefit, increasing state GDP, real consumption and employment by $1-2 \%$ for $41-65 \%$ GHG reductions from the BAU, and creating $450,000-760,000$ additional jobs in the process [29]. Like other scenario-based studies, this study examined scenarios in which the state's 2030 emissions milestones were achieved with fundamental changes in the state's energy and transportation systems, including extensive diffusion of electric vehicles. Complementary policies examined in the study include energy efficiency standards, a renewable portfolio standard, as well as aggressive policies to electrify transportation. In addition, the report demonstrates how emissions offset credits can offer significant benefits to the state by lowering allowance prices, and providing adjustment flexibility during the transition to a lowcarbon economy.

The net economic benefits found in this study stem largely from reduced energy expenditures that accrue to consumers and enterprises from energy efficiency. The higher costs of new and efficient technologies is outweighed by these energy savings and more importantly, these new consumption patterns, both for low-carbon energy supplied by in-state resources and shifting consumption to non-energy items, shift consumption away from import-dependent and relatively lower employment ratio per state GDP fossil fuels and towards employment-intensive in-state goods and services that tend to provide many more California jobs.

\subsection{REMI PI+ model for Southern California}

A macroeconomic model (REMI PI+) is adopted by Wei and Rose [22] to analyze the macroeconomic impacts of AB32 and SB375 The Sustainable Communities and Climate Protection Act of 2008 - on the economy of Southern California. This analysis uses as inputs a specific set of mitigation options identified for the Southern California Association of Governments (SCAG) Region. A total of 28 GHG mitigation policy options related to energy supply, residential/commercial/industrial demand, and agriculture/ forestry/waste management, Transportation and Land Use and Transportation System and Investments were examined by independent Technical Working Groups for the microeconomic impacts. Results show that the 28 mitigation options examined aggregately can reduce 63.0 $\mathrm{MMTCO}_{2} \mathrm{e}$ of GHG emissions (or 29.5\% from the baseline level) in the $2012-2035$ period and the weighted average cost-effectiveness of the options (using GHG reduction potentials as weights) is approximately $-\$ 3.7 / \mathrm{tCO}_{2} \mathrm{e}$ emissions reduced [22].

These microeconomic results of the policies examined (including capital, labor, O\&M, financing, and administrative costs for different mitigation technologies and policies) were mapped into the Regional Economic Models, Inc. (REMI) Policy Insight Plus $(\mathrm{PI}+)$ Macroeconometric Model to ascertain the total economic impacts. The REMI PI+ Model integrates several major economic modeling approaches, including input-output (I-O), General Equilibrium (GE), econometric, and economic geography [30]. The Model simulates the impacts of policies on both the incremental capital and production costs of affected sectors and the corresponding stimulus effects to the sectors that provide generation equipment, construction and installation services, and financing services. It also captures the indirect (macroeconomic) effects of changes in consumer and business spending resulting from those costs and savings. Potential displacement of other government spending and ordinary business investment by the new spending and investment anticipated to implement the policies, as well as the extent to which spending was funded by resources from outside the modeling region are also considered in the modeling.

\subsection{California Low Carbon Grid Study (LCGS)- phase I}

The LCGS-Phase I is a single year (2030) deterministic snapshot model using a Western Interconnection-wide chronological security constrained (38 nodes) economic dispatch production cost model (PLEXOS) to analyze the operational emissions, investments and savings for potential future electricity grids supplying electricity for California [20]. The LCGS study does not provide an optimized portfolio of generation, transmission and storage resources to meet carbon targets, but rather is an analysis of the operational considerations for specific future grid mixes. The first is a Target Case achieving a 58\% reduction from 2010 levels in carbon emissions required to serve California load, and the second is an Accelerated Case where emissions in the electric sector reach $71 \%$ below 2010 level. These two grid mixes are input assumptions and the purpose of the detailed treatment of the electricity sector demonstrated in this study is to analyze the robustness of these future grid scenarios (high renewable penetration and low cooperation between balancing authorities) as well as to examine their rate impacts.

The renewables penetrations assumed are 33\%, 57\% and 67\% under the Baseline, Target and Accelerated scenarios, respectively. The study find that with aggressive energy efficiency improvement and demand management, net savings can be achieved in the Target Case at $\$ 0.6 / \mathrm{MWh}$ or $-0.4 \%$ of 2012 electricity rate. The net costs include capital, fixed O\&M, efficiency and demand response program costs, and capacity payments, and savings include fuel, variable $0 \& M$, and carbon credit costs. The potential new storage required is $1.5 \mathrm{GW}, 3.7 \mathrm{GW}$ and $5.9 \mathrm{GW}$ for the Baseline, Target and Accelerated scenarios, respectively. The renewable curtailment (a reduction of outputs from their potentials in order to maintain grid stability or achieve economic optimality) is estimated at $1 \%, 2.7 \%$ and $12 \%$, respectively.

\section{Comparison of modeling results}

This section discusses the specific impacts in key sectors by 2030 from the modeling efforts. It is important to note that the technologies, resources and mitigation options used to meet the GHG targets are input assumptions for all of the models reviewed here except for CA-TIMES, where they are modeling results. When 
comparing specific results (such as technology adoption or GHG emissions for a given sector) across models, it is worth noting that results must be understood in the context of emissions tradeoffs made in the models (i.e. less aggressive adoption of low-carbon technologies in one sector oftentimes implies more aggressive reductions elsewhere). For simplicity, the comparison of results by sector focuses on the "main" scenarios and readers are encouraged to read individual models' publications for the full range of results. To the extent possible, we also compare in Section 3 some of the key indicators with committed policy goals or targets in order to provide context to the results. The results are also useful to identify potential policy challenges when there is a large gap between modeling results and policy goals/targets. In many cases, however, the policy goals/targets are used as input assumptions to drive modeling results (e.g. CALGAPS) or models are adjusted to meet/ exceed known policy targets prior to 2020 . Therefore, the fact that these models show that we can meet/exceed policy goals/targets does not serve as an evidence or endorsement that the policy targets/goals can be met. In a few cases, some of the policy goals/ targets were already influenced by the modeling results from some of the earlier versions of the models. We also separate out policy goals vs. targets to indicate whether a policy has been adopted (target) or is still an inspiration goal that needs to be adopted by the legislation.

Fig. 1 shows the reference scenarios of four models and the range of emission reduction trajectories across the four economywide models. These models show a range of 2030 emission levels that are $20-47 \%$ below the 1990 level (230-376 $\left.\mathrm{MMTCO}_{2} \mathrm{e}\right)$ that will eventually meet the 2050 target (except CALGAPS S2 and S3 scenarios). We select S1 scenario, as opposed to S0 scenario, as the reference scenario for CALGAPS as it is in line with the other models' reference scenarios. Reference emissions from the BEAR model are higher than the other models because it assumes a constant overall emission intensity after 2015. CALGAPS S3 scenario has an aggressive and early emission reduction trajectory and achieves far lower cumulative emissions by 2050 albeit failing to meet the 2050 target (Fig. 1, bottom right). From a climate perspective, near-term reductions are preferable to delayed reductions [9]. The results show that encouraging early emission reduction pathways can help minimize the total cumulative emissions between now and 2050. This is a lesson we learned in the previous exercise [13], but it is worth emphasizing again as it has affected policymakers' view on setting the 2030 target [31].

We summarize the key results by sector in the following sections. GHG emissions for the reference and the main GHG mitigation scenarios by sector in 2030 are shown in Fig. 2. Note that the definition of the sectors and the system boundaries of each sector can vary from model to model. PATHWAYS uses the ARB's Scoping Plan definition of sectors.

\subsection{Transportation}

The reference cases of all models expect that on-road transportation fuel use will remain flat or slightly decrease due to vehicle efficiency programs for vehicles and trucks. In scenarios that meet the 2050 target, reductions in emissions by 2030 generally result from a combination of vehicle miles traveled (VMT) reductions, vehicle efficiency improvements and gasoline and diesel displacement with low-carbon alternative fuels. Table 2 presents the range of key parameters assumed or realized in these models for 2030.
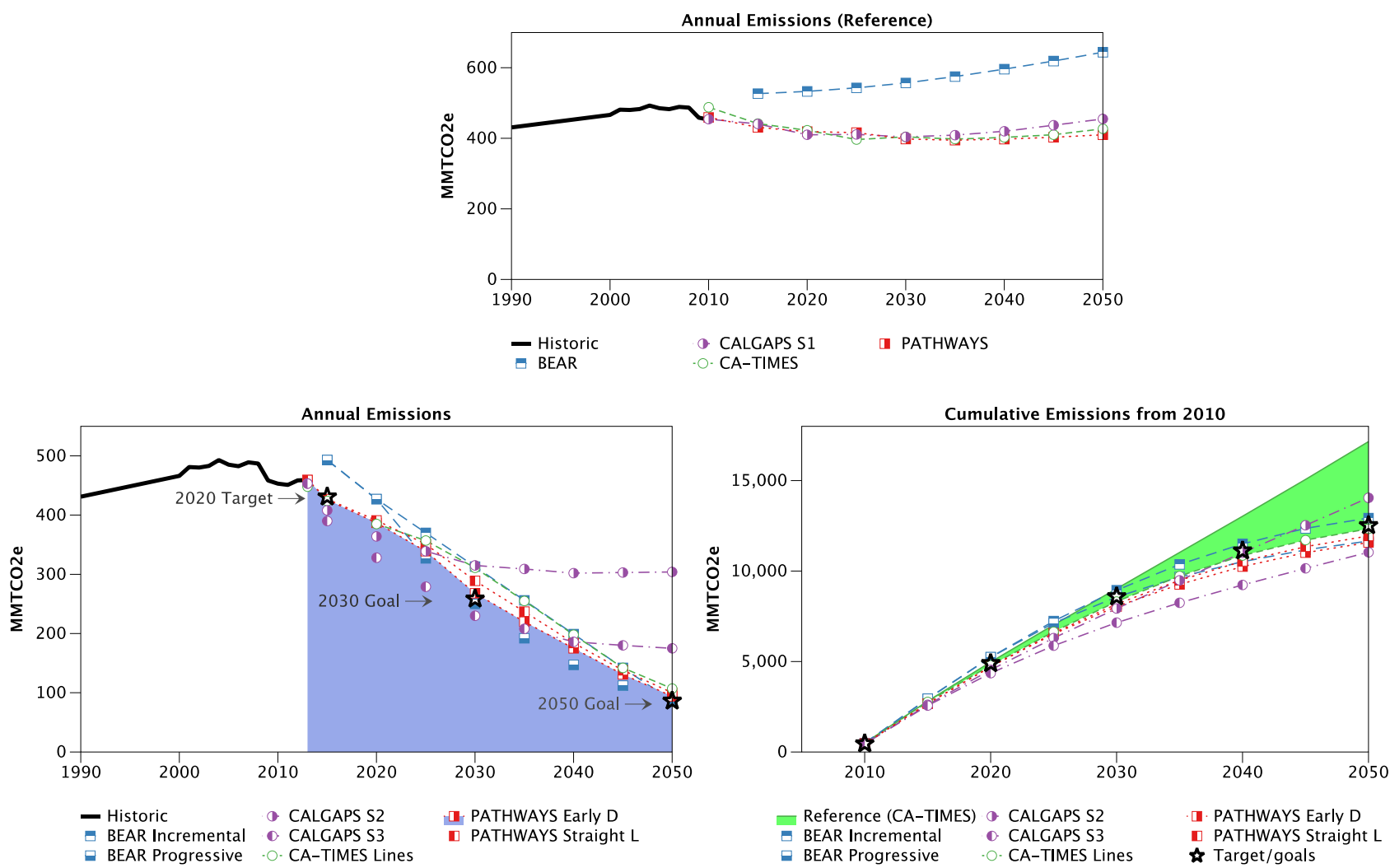

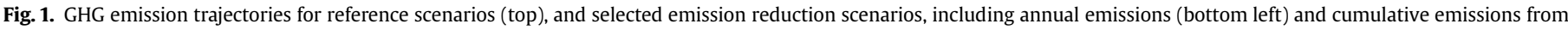

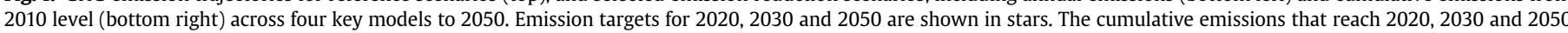

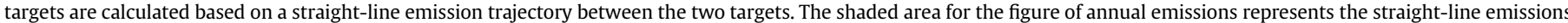

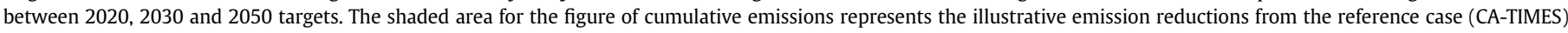
and CA-TIMES Line scenario. 


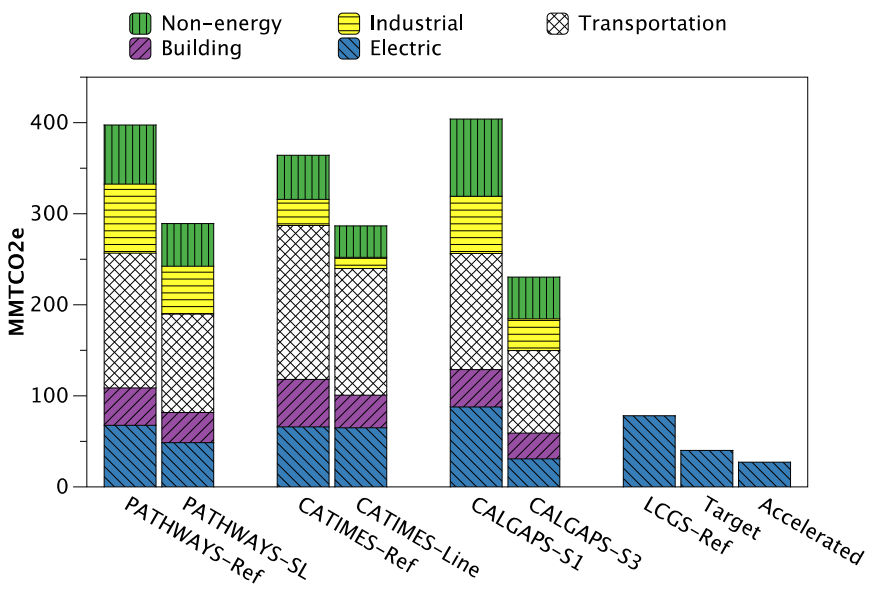

Fig. 2. GHG emissions for the reference and the main GHG mitigation scenarios by sector in 2030. Note that the definition of the sectors and the system boundaries of each sector can vary from model to model.

In the light-duty vehicle (LDV) sector, the number of zeroemission vehicles (ZEVs) ${ }^{2}$ on the road in 2030 that may be necessary to enable the state to achieve the 2050 emissions target is between 2.5 (CA-TIMES) to 16 million ZEVs (BEAR) (or about 30-100\% new vehicle sales), including 2-4 million battery electric vehicles (BEVs) in 2030, well above the Governor's target for 2025 (of 1.5 million ZEVs) [32] and 216,000 ZEVs currently on the road in California. The models do not indicate how these purchases come about (e.g. consumer or fueling incentives, or cost reductions) [12,34-36]. The total reduction in on-road petroleum use in 2030 ranges from 19 to 53\% compared to 2010 (compared to the 50\% goal announced by the Governor in 2015 [31]). Total transportation GHG emission reductions in 2030 (\% emission reduction relative to the reference scenarios) range from 20 to $32 \%$.

\subsection{Electricity}

Table 3 summarizes key technologies and performance metrics of the electric sector. The economy-wide models suggest that total demand for electricity changes from 306 TWh in 2013 to $317-415$ TWh in 2030. The total generation of electricity typically grows in these scenarios, due to increasing electrification of enduse sectors (e.g. replacing natural gas or petroleum usage) offsetting lower electricity use due to end-use efficiency improvements. This demand increase due to electrification is not anticipated by the electric-sector only model in this study (LCGS, Table 3), highlighting the importance of considering inter-sectoral dependence when considering the impacts of climate policies. The reduction of the emission intensity of electricity primarily occurs via investments in new renewable generations (38-67\% in 2030). The emission intensity of electricity is reduced from the current $315 \mathrm{gCO}_{2 \mathrm{e}} / \mathrm{kWh}$ to $82-219 \mathrm{gCO}_{2 \mathrm{e}} / \mathrm{kWh}$ in 2030 and total emissions reduction range from $2 \%$ to $65 \%$ of the reference scenario in 2030. Scenarios with greater electrification leading to higher electricity demand (e.g. CA-TIMES) also have higher electricity emissions, but displace a greater amount of fossil fuel use in other sectors. The models had differing assumptions about the inclusion of storage, nuclear power and CCS, each of which could play a critical role in enabling further GHG emissions reductions and/or lowering mitigation costs.

\footnotetext{
2 ZEVs include battery electric vehicles (BEVs), plug-in hybrid electric vehicles (PHEVs) and fuel cell vehicles (FCVs)
}

\subsection{Building}

Models included in this review all implemented significant GHG emission reductions from the building sector (which includes the commercial and residential sectors). Each analysis modeled buildings differently but common mitigation strategies are improvements in building and appliance efficiency, building electrification (switching from natural gas to electric appliances), and use of lowcarbon electricity. CA-TIMES also includes some behavioral elements by including high discount rates and fuel/technology preferences for residential and commercial appliances and demand price elasticity. Key indicators for building mitigation scenarios for 2030 are compared in Table 4.

\subsection{Non-energy sector}

Non-energy GHG emissions are estimated at 61 million $\mathrm{MMTCO}_{2} \mathrm{e} / \mathrm{yr}$ in 2012 [37]. PATHWAYS and CALGAPS, which have different system boundaries of the non-energy sector, project increases in these emissions in the Reference cases to 2030 (74.3 $\mathrm{MMTCO}_{2} \mathrm{e} / \mathrm{yr}$ and $45.4 \mathrm{MMTCO}_{2} \mathrm{e} / \mathrm{yr}$ respectively) and large reductions in the policy scenario $\left(20 \mathrm{MMTCO}_{2} \mathrm{e} / \mathrm{yr}\right.$ and $39 \mathrm{MMTCO}_{2} \mathrm{e} /$ $\mathrm{yr}$ reduction respectively) through a combination of policies including accelerated phase out of hydrofluorocarbon (HFC) gas in consumer products, landfill methane capture and waste reduction, and sustainable forest management and reforestation (Table 5). CATIMES assumes proportional reductions in non-energy GHG emissions over time without any detailed assessment.

\subsection{Costs and economic impacts}

The net costs of GHG abatement generally are measured against specific costs of a reference scenario and include: (1) direct incremental cost/savings of technology, infrastructure, and fuels; (2) savings in social costs including avoided climate impacts, and health benefits from reduced air pollutants emissions [38]; and (3) macroeconomic impacts resulting from changes in the structure of the economy, labor, trades, and demands. This paper focuses on the first and third categories as PATHWAYS, CA-TIMES, and LCGS calculate category 1 costs, and BEAR and REMI PI+ include categories 1 and 3. CALGAPS does not address costs.

These studies generally find that the incremental costs for GHG abatement in 2030 can range from modest savings to modest costs as direct fuel savings from efficiency improvements and savings in technology investments due to demand reduction can sometimes outweigh the higher technology costs. PATHWAYS finds the incremental cost between $-\$ 7$ billion to $\$ 23$ billion in 2030 across six scenarios ( $-\$ 48$ to $\$ 184 / \mathrm{mo} /$ household), with the main (SL) scenario at $\$ 8 / \mathrm{mo} /$ household or $\$ 50 / \mathrm{yr} /$ capita. CA-TIMES estimates the incremental costs to meet the 2030 target between $-\$ 81$ to $\$ 33$ billion (in $2010 \$$ at $4 \%$ discount rate), equivalent to a $-\$ 100 /$ resident/yr to $\$ 38 /$ resident/yr $(-0.27 \%-0.11 \%$ of $2010-2030$ state GDP). In these cost accounting models that capture direct incremental cost/savings of technology, infrastructure and fuels, the range of cost estimates reflect the different assumptions about levels of technology adoption, efficiency improvement, and resource utilization in the reference scenario.

BEAR and REMI examine the macroeconomic impacts of specified mitigation actions [22,29], including direct mitigation costs and indirect effects (including multiplier effects, producer and consumer response, and substitution patterns among capital, labor, and energy). Both models suggest that the overall impacts to the state and regional economy can be slightly positive, driven by the fact that (1) climate policies generally lead to economic benefits from direct fuel savings, and reductions in aggregate investments 
Table 2

Indicators of transportation sector performance metric in 2030.,

\begin{tabular}{|c|c|c|c|c|}
\hline & $\begin{array}{l}\text { PATHWAYS Straight Line (SL) } \\
\text { scenario }\end{array}$ & CA-TIMES GHG-Line scenario & CALGAPS S3 scenario & Committed state policy/goal \\
\hline \multicolumn{5}{|l|}{ Passenger mode only } \\
\hline Passenger VMT reduction (\%) & $8 \%$ & $11 \%$ & $23 \%$ & \\
\hline Light-duty ZEV & $\begin{array}{l}1.5 \text { million BEVs, } \\
2.7 \text { million PHEVs, and } \\
2.5 \text { million FCVs ( } 57 \% \text { of new } \\
\text { vehicle market share); } 2.56 \\
\text { million BEVs ( } 0.5 \text { million BEVs, } \\
0.7 \text { million FCVs, and } 1.3 \text { million } \\
\text { PHEVs) in } 2025 \text {. }\end{array}$ & $\begin{array}{l}2.25 \text { million BEVs } \\
(0.2 \text { million PHEVs })\end{array}$ & $\begin{array}{l}12 \% \text { fleet ( } 1.2 \text { million) ZEVs } \\
\text { (FCV and BEV) and } 1.7 \text { million } \\
\text { PHEVs }\end{array}$ & $\begin{array}{l}1.5 \text { million ZEVs by } 2025 \\
\text { (mandate) [49] }\end{array}$ \\
\hline Vehicle fleet efficiency & $\begin{array}{l}\text { Fuel economy standards for } \\
\text { new light-duty gasoline autos } \\
\text { are assumed to increase from } \\
26 \text { miles/gallon in } 2010 \text { to } 53 \\
\text { miles/gallon in } 2030 \text {. Similar } \\
\text { increases in fuel economy are } \\
\text { included for other vehicle } \\
\text { classes. }\end{array}$ & $\begin{array}{l}\text { On-road efficiency increases } \\
77 \% \text { compared to } 2010\end{array}$ & $\begin{array}{l}\text { On-road efficiency doubles } \\
\text { compared to } 2010\end{array}$ & $\begin{array}{l}\text { EPA/NHTSA vehicle economy } \\
\text { standard for new cars and } \\
\text { trucks are expected to increase } \\
\text { to } 56.2 \text { mpg in } 2025 \text { from } \\
36 \text { mpg today for cars, and } \\
40.3 \text { mpg for trucks from } \\
25.5 \text { mpg today (proposed } \\
\text { standards) [50] }\end{array}$ \\
\hline \multicolumn{5}{|l|}{ All modes } \\
\hline $\begin{array}{l}\text { Medium- and heavy-duty ZEVs } \\
\quad(000)\end{array}$ & 95 & 0 & 0 & $\begin{array}{l}\text { Deploy over } 100,000 \text { freight } \\
\text { vehicles and equipment } \\
\text { capable of zero emission } \\
\text { operation and maximize near- } \\
\text { zero emission freight vehicles } \\
\text { and equipment powered by } \\
\text { renewable energy by } 2030 \text { (law, } \\
\text { SB350) }\end{array}$ \\
\hline $\begin{array}{l}\text { Biomass-based fuels (billion } \\
\text { gasoline gallon equivalent, } \\
\text { gge) }\end{array}$ & 3.76 (biodiesel and biogas) & $\begin{array}{l}5.9 \text { ( } 20 \% \text { of all transportation } \\
\text { fuel) }\end{array}$ & $\begin{array}{l}3.5 \text { (17\% of all transportation } \\
\text { fuel) }\end{array}$ & \\
\hline $\begin{array}{l}\text { Carbon intensity }(\mathrm{CI}) \text { of fuels } \\
\text { (\% reduction from } 2010)\end{array}$ & $22 \%$ & $20 \%$ & $12 \%$ & $\begin{array}{l}\text { Carbon intensity } \\
\text { reduction }>10 \% \text { by } 2030 \text { (law, } \\
\text { SB350) }\end{array}$ \\
\hline $\begin{array}{l}\text { Total transportation fuel } \\
\text { demand (PJ) }\end{array}$ & 2018 & 3400 & $3037(\mathrm{~S} 2)-2494(\mathrm{~S} 3)$ & \\
\hline $\begin{array}{l}\text { Reduction in gasoline and } \\
\text { diesel use from on-road } \\
\text { transportation (\% reduction } \\
\text { from 2010) }\end{array}$ & $30 \%$ & $38 \%$ & $53 \%$ & $\begin{array}{l}\text { Reducing petroleum use in cars } \\
\text { and trucks by up to } 50 \% \text { by } 2030 \\
\text { (goal) [31] }\end{array}$ \\
\hline Mitigation $\operatorname{Cost}^{\mathrm{d}}$ & $\begin{array}{l}\text { - } \$ 93 \text { (real, levelized } 2012 \$ \text { / } \\
\text { household/yr) for LDV } \\
\$ 315 \text { ( } 2012 \$ / \text { vehicle/yr) for } \\
\text { trucking and busing }\end{array}$ & $\begin{array}{l}\$ 112 / \text { tonne in LDV sector }(\$ 10 / \\
\text { household/yr) (real, levelized } \\
2010 \$ \text { ) }\end{array}$ & Not calculated & \\
\hline $\begin{array}{l}\text { Total transportation emission } \\
\text { reductions in 2030, } \\
\mathrm{MMTCO}_{2} \mathrm{e} \text { (\% emission } \\
\text { reduction) relative to the } \\
\text { reference scenario }\end{array}$ & $40 \mathrm{MMTCO}_{2} \mathrm{e}(27 \%)$ & $30 \mathrm{MMTCO}_{2} \mathrm{e}(18 \%)$ & $\begin{array}{l}37 \mathrm{MMTCO}_{2} \mathrm{e} \text { relative to } \mathrm{S} 1 \\
(29 \%)\end{array}$ & \\
\hline
\end{tabular}

a Zero emission vehicles (ZEVs) include full battery electric vehicles (BEVs), plug-in hybrid vehicles, and hydrogen fuel cell vehicles (FCVs).

b The range presented here does not necessarily represent the full range of scenarios conducted by each modeling group. Rather, only "representative" scenarios are selected

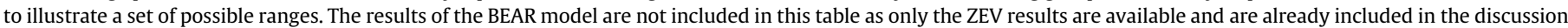
in the text.

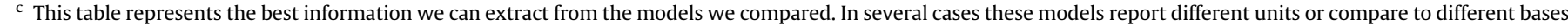
or different system boundaries. It is difficult to have all the comparisons on the same basis.

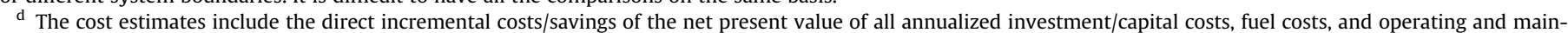

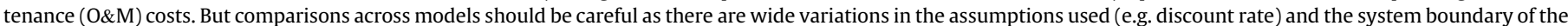
calculations (e.g. whether and how infrastructures costs such as grid expansion, charging station, etc are included).

for end-use and upstream technologies (particularly vehicle and fuels infrastructure) over the long-term [18,39], and (2) The fossil fuel supply chain (including the oil and gas, oil refinery, electric power, and natural gas sectors) is among the least employment intensive in the economy [29]. Sectors such as retail, services, and construction, that are stimulated by carbon abatement activities from direct fuel savings and expenditure shifting are more laborintensive than those projected to decline due to the climate policies [29]. The combination of these two effects leads to shifts in household spending away from energy purchases towards higheremployment economic sectors (i.e. state economic output increases due to higher multipliers on consumer spending on services versus energy).

\section{Discussion}

\subsection{Consistent findings}

It's worth highlighting the consistent findings across a range of the models that we examined. In order to achieve significant GHG emission reductions on the order of $40 \%$ below the 1990 level in 2030, a combination of the following strategies are essential:

- significant improvements in energy efficiency in the supply and end-use sectors (including buildings, transportation, and industrial sectors), 
Table 3

Key indicators for 2030 electricity generation and demands.

\begin{tabular}{|c|c|c|c|c|c|}
\hline & PATHWAYS SL scenario & Low Carbon Grid Study ${ }^{a}$ & $\begin{array}{l}\text { CA-TIMES GHG-Line } \\
\text { scenario }\end{array}$ & CALGAPS S3 & $\begin{array}{l}\text { Committed state policy/ } \\
\text { goal }\end{array}$ \\
\hline $\begin{array}{l}\text { Modeling approach and } \\
\text { temporal resolution }\end{array}$ & $\begin{array}{l}\text { Hourly supply simulated } \\
\text { using a dispatch model. } \\
\text { Renewable capacity } \\
\text { decisions are user inputs }\end{array}$ & $\begin{array}{l}\text { Expert-determined } \\
\text { generation mix with } \\
\text { PLEXOS production cost } \\
\text { modeling. Renewable } \\
\text { generation is added to } \\
\text { meet the study's } 2030 \\
\text { emission target }\end{array}$ & $\begin{array}{l}\text { Simplified optimized } \\
\text { dispatch and capacity } \\
\text { additions with } 48 \text { sub- } \\
\text { annual timeslices. } \\
\text { Renewable capacity/ } \\
\text { generation is } \\
\text { endogenously } \\
\text { determined by the model }\end{array}$ & $\begin{array}{l}\text { Developed electricity } \\
\text { mixes that are consistent } \\
\text { with state policies. Annual } \\
\text { resolution. Renewable } \\
\text { generation is added } \\
\text { according to S3 policy } \\
\text { descriptions }\end{array}$ & \\
\hline $\begin{array}{l}\text { Total electricity demand } \\
\text { (TWh) }\end{array}$ & 317 & 321 & $411-415$ & 340 & \\
\hline $\begin{array}{l}\% \text { Renewable Generation } \\
\text { (\% of sales) }\end{array}$ & $\begin{array}{l}50 \% \text { (not including } \\
\text { distributed generation or } \\
\text { large hydro) }\end{array}$ & $\begin{array}{l}57 \% \text { in Target case and } \\
67 \% \text { in accelerated case } \\
\text { (not including distributed } \\
\text { generation or large hydro) }\end{array}$ & $\begin{array}{l}38-49 \% \text { (not including } \\
\text { large hydro) }\end{array}$ & $\begin{array}{l}51 \% \text { (not including } \\
\text { distributed generation or } \\
\text { large hydro) }\end{array}$ & $\begin{array}{l}\text { 50\% by } 2030 \text { (mandate, } \\
\text { SB350) }\end{array}$ \\
\hline Storage technologies & $\begin{array}{l}\text { Battery storage and } \\
\text { pumped hydro. Flexible } \\
\text { loads and demand } \\
\text { response. Flexible } \\
\text { hydrogen production in } \\
\text { one scenario }\end{array}$ & $\begin{array}{l}\text { Unspecified storage to } \\
\text { meet } 1500 \text { MW target and } \\
\text { additional pumped hydro } \\
\text { and compressed air } \\
\text { energy storage (CAES) }\end{array}$ & $\begin{array}{l}\text { No new capacity beyond } \\
\text { existing pumped hydro }\end{array}$ & $\begin{array}{l}\text { Unspecified storage } \\
\text { technologies ( } 6.8 \mathrm{GW})\end{array}$ & $\begin{array}{l}1.3 \mathrm{GW} \text { of batteries, grid } \\
\text { storage by } 2020 \\
\text { (mandate) }[51]\end{array}$ \\
\hline $\begin{array}{l}\text { Average electricity } \mathrm{CI} \\
\qquad\left(\mathrm{gCO}_{2} \mathrm{e} / \mathrm{kWh}\right)\end{array}$ & $\begin{array}{l}166 \text { (including imported } \\
\text { electricity) }\end{array}$ & $83-123$ & $156-197$ & 102 & \\
\hline $\begin{array}{l}\text { Incremental average } \\
\text { electricity costs } \\
(2012 \$ / \mathrm{kWh})\end{array}$ & $\begin{array}{l}\$ 0.01 / \mathrm{kWh}, \text { or } \$ 18.8 \\
-\$ 22.6(2012 \$ / \mathrm{mo} / \\
\text { household })\end{array}$ & $\begin{array}{l}\text {-\$0.6/MWh (2014\$ } \\
\text { levelized cost) }\end{array}$ & $\begin{array}{l}\$ 0.012 / \mathrm{kWh} \text { levelized } \\
\text { electricity cost }\end{array}$ & Not calculated & \\
\hline $\begin{array}{l}\text { New Nuclear/CCS } \\
\text { available }\end{array}$ & No & No & No & Yes & \\
\hline $\begin{array}{l}\text { Total electric emission } \\
\text { reductions in 2030, } \\
\text { MMTCO }_{2} \mathrm{e} \text { (\% emission } \\
\text { reduction) relative to } \\
\text { the reference scenario }\end{array}$ & $19 \mathrm{MMTCO}_{2} \mathrm{e}(28 \%)$ & $\begin{array}{l}38 \mathrm{MMTCO}_{2} \mathrm{e} \text { in Target } \\
\text { case and } 51 \mathrm{MMTCO}_{2} \mathrm{e} \text { in } \\
\text { accelerated case }(49-65 \%)\end{array}$ & $1 \mathrm{MMTCO}_{2} \mathrm{e}(2 \%)$ & $\begin{array}{l}57 \mathrm{MMTCO}_{2} \mathrm{e}(65 \% \\
\text { reduction relative to } \mathrm{S} 1)\end{array}$ & \\
\hline
\end{tabular}

a The electric sector only model is included in the electricity generation and demand comparison.

- utilization of very low-carbon electricity from renewable sources,

- decarbonization of liquid or gaseous fuels with sustainable sources of biomass,

- aggressive adoptions of ZEVs,

- demand reduction in vehicle miles traveled, and

- reductions of non-energy GHGs emissions.

These findings are similar to those from earlier studies for California [13] and elsewhere [40,41], suggesting that to achieve significant emission reductions by 2030 in California and elsewhere similar solutions and technology options are needed.

Results of the economic analysis suggest that the direct economic costs of GHG mitigation activities in 2030 can be achieved at fairly modest net costs or even net savings, while the indirect macroeconomic impacts are likely to be positive, as shifts in employment and capital investments could have higher economic returns than conventional energy expenditures.

Despite the above-mentioned agreements, there are significant uncertainties in the costs as well as benefits estimates. It was further emphasized at the workshop that further work is critically needed to understand the heterogeneous impacts to the population, particularly given the state laws requiring at least $25 \%$ of the annual fund from auction revenues of the cap-and-trade program be allocated to projects that directly benefit "disadvantaged" communities and at least $10 \%$ be allocated to projects located within disadvantaged communities [42].

\subsection{Bridging the gap between policymakers and modelers}

In this section we offer additional thoughts on bridging the gap between what these models can tell us versus what the policymakers need to know to implement effective and targeted policies.

\subsubsection{Communicating model assumptions and results}

Compared with the previous CCPM workshop [13], we observe improvements in greater transparency in the publication of detailed assumptions in more accessible formats, and more reporting of modeling results in terms of performance metrics that are essential for developing policy measures such as energy efficiency (e.g. $\mathrm{gCO}_{2} \mathrm{e} / \mathrm{mile}$ for vehicles), carbon intensity $\left(\mathrm{gCO}_{2} \mathrm{e} / \mathrm{MJ}\right.$ or $\mathrm{gCO}_{2} \mathrm{e} / \mathrm{kWh}$ ) of energy, and changes in household energy expenditures (in $\$ / \mathrm{mo} /$ household or $\$ /$ household/year), etc.

\subsubsection{The role of uncertainty}

As we mentioned previously, models reviewed in this study all conducted extensive sensitivity or uncertainty analyses and readers are encouraged to read these studies for a better understanding of the uncertainties associated with each model and scenarios. Here we briefly mention major uncertainties common across all models.

The uncertainties with regards to the reference case, inputs assumptions, and assumptions about policy instruments were raised as a major source of uncertainty influencing the estimates of the mitigation costs. Several models and experts identified that the choice of a reference scenario is critical to the estimates of the cost of mitigation $[13,16,18,43,44]$. In this modeling comparison exercise however, the modeling teams (except the BEAR model) have an almost identical reference scenario (Fig. 1) as they all use the latest state gross domestic product (GDP), population projections, and included fully committed policies through 2020. As the future is highly uncertain, even the uncertainty of a few basic parameters such as state GDP, population growth, and future oil prices can have 
Table 4

Key indicators for 2030 emission mitigations from the building sector.

\begin{tabular}{|c|c|c|c|c|}
\hline & PATHWAYS SL scenario & CA-TIMES GHG-Line scenario & CALGAPS S3 scenario & Committed state policy/goal \\
\hline $\begin{array}{l}\text { Total reduction in energy use } \\
\text { compared to BAU in } 2030(\%)\end{array}$ & $\begin{array}{l}11 \% \text { reduction from } 1.5 \mathrm{EJ} \text { in the } \\
\text { reference case }\end{array}$ & $\begin{array}{l}6 \% \text { from } 1.0 \mathrm{EJ} \text { in the reference } \\
\text { scenario for the residential } \\
\text { sector and } 1 \% \text { from } 0.6 \mathrm{EJ} \text { for the } \\
\text { commercial sector }\end{array}$ & $15 \%$ & $\begin{array}{l}\text { Doubling of energy efficiency } \\
\text { by } 2030 \text { (mandate, SB350) }\end{array}$ \\
\hline Building electrification & $\begin{array}{l}\text { Electric heat pump HVAC \& } \\
\text { water heating large part of new } \\
\text { appliance sales starting in } 2020\end{array}$ & $\begin{array}{l}\text { Modest electrification: } 10 \% \\
\text { increase in residential sector } \\
\text { electrification and flat in } \\
\text { commercial sector vs. } 2010\end{array}$ & $\begin{array}{l}90 \% \text { new construction, } 50 \% \\
\text { retrofits }\end{array}$ & \\
\hline Service demand reduction ${ }^{a}$ & $\begin{array}{l}10 \% \text { reduction in hot water } \\
\text { demand by } 2020 \text { for residential } \\
\text { and by } 2024 \text { for commercial } \\
\text { buildings, } 4 \% \text { reduction in space } \\
\text { heating demand due to } \\
\text { improved building envelope, } 5 \% \\
\text { reduction in space cooling } \\
\text { demand due to improved } \\
\text { insulation, windows, HVAC } \\
\text { fault detection, controls, and } \\
\text { diagnostics, } 1-3 \% \text { reductions in } \\
\text { residential space heating, } \\
\text { cooling and lighting due to } \\
\text { behavioral changes by } 2024\end{array}$ & $\begin{array}{l}\text { Sensitivity scenarios with } \\
\text { elastic demand to price changes } \\
\text { result in } 1 \% \text { reduction } \\
\text { compared with the reference } \\
\text { scenario }\end{array}$ & No service demand reduction & \\
\hline Appliance efficiencies & $\begin{array}{l}\text { Electric efficiency (GWh) is } \\
\text { nearly double in the SL scenario } \\
\text { compared to current policy. } \\
\text { Largest EE savings assumed to } \\
\text { come from commercial LED } \\
\text { lighting, more efficient } \\
\text { equipment \& appliances }\end{array}$ & $\begin{array}{l}\text { Energy efficiency (EE) improves } \\
\text { by almost } 1.8 \times \text { compared to the } \\
2010 \text { level. Energy efficiency } \\
\text { increases to } 2.5 \times \text { in the } \\
\text { residential sector and } 1.9 \times \text { in } \\
\text { the commercial sector. }\end{array}$ & NA & \\
\hline Mitigation costs ${ }^{b}$ & $\begin{array}{l}\text { Levelized costs ( } 2015-2030) \text { : } \\
\$ 15.6(2012 \$) / \text { household/yr in } \\
\text { direct household appliance and } \\
\text { building cost and } \$ 37.2 \\
(2012 \$) / 1000 \text { sqft/yr in direct } \\
\text { appliance and building costs } \\
\text { not including fuel savings nor } \\
\text { the cost of goods and services }\end{array}$ & $\begin{array}{l}\text { Levelized costs ( } 2010-2030) \text { : } \\
\$ 1.5 / \text { household/yr relative to } \\
\text { the reference scenario in the } \\
\text { residential sector and }-\$ 17 / \\
1000 \text { sqft/yr relative to the } \\
\text { reference scenario in the } \\
\text { commercial sector. }\end{array}$ & Not calculated & \\
\hline $\begin{array}{l}\text { Total building emission } \\
\text { reductions in 2030, } \\
\mathrm{MMTCO}_{2} \mathrm{e} \text { (\% emission } \\
\text { reduction) relative to the } \\
\text { reference scenario }\end{array}$ & $7.9 \mathrm{MMTCO}_{2} \mathrm{e}(19 \%)$ & 16.3 $\mathrm{MMTCO}_{2} \mathrm{e}(31 \%)$ & $\begin{array}{l}12.7 \mathrm{MMTCO}_{2} \mathrm{e}(31 \% \text { reduction } \\
\text { relative to } \mathrm{S} 1 \text { ) }\end{array}$ & \\
\hline
\end{tabular}

a Service demand refers to demands for cooled or heated space, clothes washing, dish washing, and refrigeration for example. Service demand reduction involves changes in

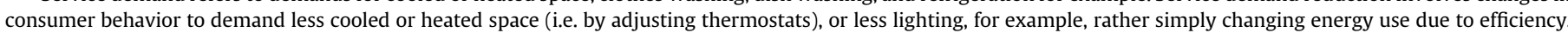

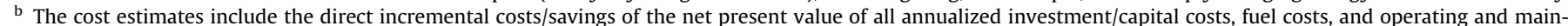

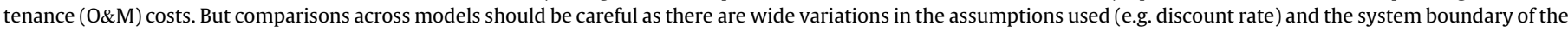
calculations.

Table 5

Key indicators for 2030 non-energy mitigation options.

\begin{tabular}{|c|c|c|c|c|}
\hline & PATHWAYS SL scenario & CA-TIMES GHG-Line scenario & CALGAPS S3 scenario & Committed state policy/goal \\
\hline Mitigation options & $\begin{array}{l}\text { High mitigation potential from } \\
\text { F-gases, methane leaks and } \\
\text { some types of waste \& manure. } \\
\text { Difficult to mitigate cement, } \\
\text { enteric fermentation, other } \\
\text { agricultural non-energy GHG } \\
\text { emissions }\end{array}$ & Not specified in the model & $\begin{array}{l}\text { A combination of policies } \\
\text { including accelerated phase out } \\
\text { of hydrofluorocarbon (HFC) gas } \\
\text { in consumer products, landfill } \\
\text { methane capture and waste } \\
\text { reduction, and sustainable } \\
\text { forest management and } \\
\text { reforestation }\end{array}$ & $\begin{array}{l}\text { Implementation of proposed } \\
\text { Short-Lived Climate Pollutant } \\
\text { Strategy by } 2030 \text { (Law, SB350) } \\
\text { - } 40 \% \text { reduction in methane } \\
\text { and hydrofluorocarbon } \\
\text { emissions } \\
\text { - } 50 \% \text { reduction in black } \\
\text { carbon emissions }\end{array}$ \\
\hline $\begin{array}{l}\text { Total non-energy emission } \\
\text { reductions in 2030, } \\
\mathrm{MMTCO}_{2} \mathrm{e} \text { (\% emission } \\
\text { reduction) relative to the } \\
\text { reference scenario }\end{array}$ & $18 \mathrm{MMTCO}_{2} \mathrm{e}(28 \%)$ & $14 \mathrm{MMTCO}_{2} \mathrm{e}(29 \%)$ & $\begin{array}{l}39 \mathrm{MMTCO}_{2} \mathrm{e}(46 \% \text { reduction } \\
\text { relative to } \mathrm{S} 1) \text {. }\end{array}$ & \\
\hline
\end{tabular}

huge impacts on the estimated reference case [17,44]. Though using a common reference scenario across models has the advantage of comparing the results on a consistent basis, it can give a false sense of certainty.
The uncertainties about future technology costs, resource costs and limits (particularly for biofuels), the availability of certain key technologies especially CCS and nuclear, assumptions about the efficiency of buildings and power generation technologies are 
among the most sensitive assumptions that affect the estimates of mitigation costs and measurable GHG mitigation impacts of certain pathway or technology [16-18]. Even though policy instruments are not the focus of this workshop, the two economic models both find that specific policy instruments and their implementation strategies, such as GHG emission allowance allocation/recycling/ offsets alternatives for the cap-and-trade program [21] and incentives to encourage R\&D investments and in-region production of green technologies [22], can have profound impacts on the costeffectiveness and the aggregate and distributional impacts of climate policies in California.

\subsubsection{Model limitations and the "ideal" model}

The purpose of all these models is not to make projections but to document the degree of implicit coordination between sectors necessary to reach the 2050 goal and to evaluate the potential cost implications. Each model presented in the workshop has a number of important limitations that are important for policymakers and other observers to keep in mind when interpreting and relying on their outputs to develop policies. Below is a list (in no particular order) of model capabilities that CCPM participants identified as the most helpful for models to provide direct policy inputs:

- Quantify direct consumer expenditure impacts across all services/sectors (net increases or decreases in expenditure for energy services, capital and fuel), and macroeconomic costs and benefits associated with the adoption of low-carbon technologies (employment, state GDP, multiplier effect).

- Detailed bottom up technology and cost description of future technologies (with appropriate representation of uncertainty).

- Behavioral model to adequately represent consumer heterogeneity across income classes, regional differences, risk preferences and taste variation to understand how policies, incentives, technologies and other factors will influence the adoption of low-carbon fuels and technologies.

- Detailed representation of policies/regulations and consumer and industry responses and heterogeneity of impacts across sectors and income groups.

- Representation of endogenous innovation in response to technology-forcing policies.

- Ways to test for robustness of policies given uncertainties.

Some of these elements can be incorporated into the models presented at the workshop to improve their usefulness for policymakers. The challenge is that many of these elements would be difficult to implement in these models (due to computational time, model structure, etc.), and there is a fundamental lack of knowledge and data to implement these improvements in different modeling frameworks. For example, more research is needed to know about the underlying decision and behavioral processes of consumers in purchasing new technologies [45], especially when future technology attributes can be significantly modified $[36,46]$. There are significant hurdles to overcome before these types of behavioral models can be of use to policymakers, including data availability, theoretical concepts $[45,47]$, and the broader applicability and robustness across space, time, and technologies.

\subsubsection{Thoughts about the policy and modeling dialogue}

This paper presents an example of how policymakers, energy system modelers and stakeholders interact and work together to develop and evaluate long-term state climate policy targets. The purpose of the CCPM dialogue is to create a constructive dialogue between policymakers and modelers, where each is giving and receiving the most useful and relevant information that they need in order to do their work effectively. For policymakers, the most important interaction that they can provide to modelers is policymaker's needs with respect to technical, economic and modeling information in the process of developing and setting policy. For modelers, the most important interaction with the policymakers is to provide targeted information allowing policymakers to develop scenarios evaluating policy design, program outcomes, key areas of uncertainties, and performance matrix.

There needs to be a certain level of independence in this collaboration process so that modelers can provide independent assessments with regards to the feasibility, and costs/benefits, of the proposed target goals and targets. In addition, the results from illustrative scenario analysis can be informative at a very broad level, but may provide little guidance on how policy details should be designed. It is not always clear, and often debatable, which policy options (e.g. purely market-based vs. technology-forcing policies or performance standards) are the best policy tools to deliver the intended outcomes at relatively low costs and without disproportionate impacts across different segments of the population. Careful considerations of the pros and cons of each of these options toward the 2030 targets are beyond the scope of this workshop but will be the focus of the policy formulation process in California for the next several years [2]. Even though this paper focuses on California, the process of interactions, modeling results, and lessons learned can be generally adopted across different regions and scales.

\section{Acknowledgement}

This research and the workshop is partly supported by the California Air Resources Board (award \# 14-8008). Co. Funding for the PATHWAYS model was provided by the California Air Resources Board, the California Energy Commission, California Public Utilities Commission, the California Independent System Operator, and the Energy Foundation. Yeh and Yang acknowledge funding support from the Sustainable Transportation Energy Pathways (STEPS) program and California Air Resources Board (award \# 09-346) for the development of CA-TIMES model. Roland-Holst acknowledges funding support from Next10 for the latest model revision. Greenblatt acknowledges funding support from California Air Resources Board for the CALGAPS model (award \# 12-329). We appreciate the comments and feedback provided by Brad Neff, Sonika Choudhary and Xantha Bruso. We also thank two anonymous reviewers whose comments have significantly improved the quality of this paper. Any errors and omissions are the responsibility of the authors alone.

\section{References}

[1] ARB, AB 32 Climate Change Scoping Plan Document, 2009.

[2] ARB, Proposed First Update to the Climate Change Scoping Plan: Building on the Framework, California Air Resources Board, 2014.

[3] M. Hanemann, California's new greenhouse gas laws, Rev. Environ. Econ. Policy 2 (1) (2008) 114-129.

[4] G. Franco, et al., Linking climate change science with policy in California, Clim. Change 87 (1) (2008) 7-20.

[5] A.D. Ray, J. Grannis, From planning to action: implementation of state climate change adaptation plans, Mich. J. Sustain. 3 (Spring) (2015) 5-28.

[6] D. Kammen, B.L.P. Henríquez, J. Johnston, California's climate policy and the development of clean energy systems insititutional foundations, in: A. Bumpus, et al. (Eds.), Carbon Governance, Climate Change and Business Transformation, Routledge, New York, NY, 2015.

[7] E.G. Brown Jr., in: S.o.C. Office of Governor (Ed.), Executive Order B-30-15, Office of Governor, Sacramento, State of California, 2015.

[8] J. Köhler, et al., The transition to endogenous technical change in climateeconomy models: a technical overview to the innovation modeling comparison project, Energy J. 27 (2006) 17-55.

[9] IPCC, in: O. Edenhofer, R. Pichs-Madruga, Y. Sokona, E. Farahani, S. Kadner, K. Seyboth, A. Adler, I. Baum, S. Brunner, P. Eickemeier, B. Kriemann, J. Savolainen, S. Schlöer, C. von Stechow, T. Zwickel, J.C. Minx (Eds.), Climate Change 2014: Mitigation of Climate Change. Contribution of Working Group 
III to the Fifth Assessment Report of the Intergovernmental Panel on Climate Change, Cambridge University Press, Cambridge, United Kingdom and New York, NY, USA, 2014

[10] G. Luderer, et al., The economics of decarbonizing the energy system-results and insights from the RECIPE model intercomparison, Clim. Change 114 (1) (2012) 9-37.

[11] M. Tavoni, et al., Post-2020 climate agreements in the major economies assessed in the light of global models, Nat. Clim. Change 5 (2) (2015) 119-126.

[12] C. Liu, D.L. Greene, Analyzing the role of subsidies in motor vehicle electrification in the US, in: 26th Electric Vehicle Symposium 2012, 2012.

[13] G.M. Morrison, et al., Comparison of low-carbon pathways for California, Clim. Change (2015) 1-13.

[14] O. Edenhofer, et al., Induced technological change: exploring its implications for the economics of atmospheric stabilization: synthesis report from the innovation modeling comparison project, Energy J. 27 (2006) 57-107.

[15] ARB, Mobile Source Strategy. Discussion Draft, California Air Resources Board, 2015.

[16] A. Mahone, et al., California PATHWAYS: GHG Scenario Results, in: Energy+Environmental Economics, 2015

[17] J.B. Greenblatt, Modeling California policy impacts on greenhouse gas emissions, Energy Policy 78 (0) (2015) 158-172.

[18] C. Yang, et al., Achieving California's 80\% greenhouse gas reduction target in 2050: technology, policy and scenario analysis using CA-TIMES energy economic systems model, Energy Policy 77 (0) (2015) 118-130.

[19] D. Roland-Holst, Energy Efficiency, Innovation, and Job Creation in California, Department of Agricultural and Resource Economics, University of California, Berkeley, CA, 2008

[20] G. Brinkman, J. Jorgenson, M. Hummon, California 2030 Low Carbon Grid Study (LCGS): Phase I, 2015. Available from: http://lowcarbongrid2030.org.

[21] A. Rose, D.A.N. Wei, F. Prager, Distributional impacts of greenhouse gas emissions trading: alternative allocation and recycling strategies in California, Contemp. Econ. Policy 30 (4) (2012) 603-617.

[22] D. Wei, A. Rose, Macroeconomic impacts of the California global warming solutions act on the Southern California Economy, Econ. Energy \& Environ. Policy 3 (2) (2014) 101-118.

[23] K. Train, Qualitative Choice Analysis: Theory, Econometrics, and an Application to Automobile Demand, The MIT Press, Cambridge, 1993.

[24] K. Gillingham, K. Palmer, Bridging the Energy Efficiency Gap: Insights for Policy from Economic Theory and Empirical Analysis, Resources For the Future, Washington, DC, 2013.

[25] M.J. Grubb, J. Kohler, D. Anderson, Induced technical change in energy and environmental modeling: analytic approaches and policy implications, Annu. Rev. Energy Environ. 27 (2002) 271-308.

[26] A. Loschel, Technological change in economic models of environmental policy: a survey, Ecol. Econ. 43 (2,Äì) (2002) 105-126.

[27] D. McCollum, et al., Deep greenhouse gas reduction scenarios for California Strategic implications from the CA-TIMES energy-economic systems model, Energy Strategy Rev. 1 (1) (2012) 19-32.

[28] D. Roland-Holst, Berkeley Energy and Resources (BEAR) Model Technical Documentation for a Dynamic California CGE Model for Energy and Environmental Policy Analysis, University of California, Berkeley, 2015.

[29] D. Roland-Holst, California Climate Policy to 2050: Pathways for Sustained Prosperity, 2015. Next 10. Url: http://next10.org/sites/next10.org/files/FINAL\% 20Climate\%20Pathways\%202015.pdf.

[30] REMI, The REMI Model, 2015. Available from: http://www.remi.com/theremi-model.
[31] ARB, 2030 Target Scoping Plan Update Concept Paper, California Air Resources Board, 2016.

[32] E.G. Brown Jr., in: S.o.C. Office of Governor (Ed.), Executive Order B-16-2012 Office of Governor, Sacramento, State of California, 2014.

34] NREL, California Statewide Plug-in Electric Vehicle Infrastructure Assessment. CEC-600-2014-003, National Renewable Energy Laboratory, 2014.

[35] CEC, 2014-2015 Investment Plan Update for the Alternative and Renewable Fuel and Vehicle Technology Program, 2014. April. CEC Commission Report CEC-600-2013-003-CMF, http://www.energy.ca.gov/2013publications/CEC600-2013-003/CEC-600-2013-003-CMF.pdf.

[36] Z. Lin, D.L. Greene, Promoting the market for plug-in hybrid and battery electric vehicles: role of recharge availability, Transp. Res. Rec. J. Transp. Res. Board 2252 (2011) 49-56.

[37] ARB, Greenhouse Gas Inventory Data - 2000 to 2012, 2014 [cited 2015 May 2015].

[38] C. Zapata, N. Muller, M. Kleeman, PM2.5 co-benefits of climate change legislation part 1: California's AB 32, Clim. Change 117 (1-2) (2013) 377-397.

[39] CEDP, Microeconomic and Macroeconomic Impact Analysis of Greenhouse Gas Mitigation Policy Options for the Southern California Climate and Economic Development Project (CEDP), Final Report Submitted to SCAG, Climate and Economic Development Project (CEDP), 2012.

[40] F. Creutzig, et al., Transport: a roadblock to climate change mitigation? Science 350 (6263) (2015) 911-912.

[41] O.Y. Edelenbosch, D.L. McCollum, D.P. van Vuuren, C. Bertram, S. Carrara, H. Daly, S. Fujimori, A. Kitous, P. Kyle, E. Ó Broin, P. Karkatsoulis, F. Sano Decomposing passenger transport futures: Comparing results of global integrated assessment models, Transp. Res. Part D Transp. Environ. (2016).

[42] Senate Bill No. 535. Chapter 830. California Global Warming Solutions Act of 2006: Greenhouse Gas Reduction Fund, 2012.

[43] ARB, Updated Economic Analysis of California's Climate Change Scoping Plan: Staff Report to the Air Resources Board, California Air Resources Board, 2010.

[44] S. Borenstein, et al., Expecting the unexpected: emissions uncertainty and environmental market design, in: NBER Working Paper No. w20999, 2015. Available at SSRN: http://ssrn.com/abstract $=2575485$.

[45] F. Krysiak, H. Weigt, The demand side in economic models of energy markets the challenge of representing consumer behavior, Front. Energy Res. 3 (2015).

[46] J. West, et al., Vehicle Miles (Not) Traveled: Why Fuel Economy Requirements Don't Increase Household Driving, E2e Working Paper 019, B. Energy Institute at Haas at the University of California, the Center for Energy and Environmental Policy Research (CEEPR) at the Massachusetts Institute of Technology, and the Energy Policy Institute at Chicago, University of Chicago, 2015.

[47] D.S. Bunch, et al., Incorporating Behavioral Effects from Vehicle Choice Models into Bottom-up Energy Sector Models, Research Report - UCD-ITS-RR-15-13, Institute of Transportation Studies, University of California, Davis, 2015.

[48] LCGS, Low Carbon Grid Study (LCGS) Workpapers: Assumptions for Production Cost Modeling and Revenue Requirement Impact Analysis, 2015.

[49] Governor's Interagency Working Group on Zero-Emission Vehicles, ZEV Action Plan: an Updated Roadmap toward 1.5 Million Zero-emission Vehicles on California Roadways by 2025, Governor's Interagency Working Group on Zero-emission Vehicles, 2015.

[50] ICCT, Light-duty Vehicle Efficiency Standards Factsheet: United States, The International Council on Clean Transportation, 2014.

[51] Decision Adopting Energy Storage Procurement Framework and Design Program, Order Instituting Rulemaking Pursuant to Assembly Bill 2514 to Consider the Adoption of Procurement Targets for Viable and Cost-effective Energy Storage Systems, Rulemaking 10-12-007, 2013. 